\title{
The effects of temperature and acid number of crude oil on the wettability of acid volcanic reservoir rock from the Hailar Oilfield
}

\author{
Xie Quan ${ }^{1}$, He Shunli'* and Pu Wanfeng ${ }^{2}$ \\ ${ }^{1}$ Key Laboratory of Petroleum Engineering, Ministry of Education, China University of Petroleum, Beijing 102249, China \\ ${ }^{2}$ State Key Laboratory of Oil and Gas Reservoir Geology and Exploitation, Southwest Petroleum University, Chengdu, \\ Sichuan 610500, China
}

(C) China University of Petroleum (Beijing) and Springer-Verlag Berlin Heidelberg 2010

\begin{abstract}
Wettability of acid volcanic reservoir rock from the Hailar Oilfield, China, was studied with crude oils of different acid numbers generated from an original crude oil with an acid number of $3.05 \mathrm{mg}$ $\mathrm{KOH} / \mathrm{g}$. The modified oils and their resultant acid numbers were: A (2.09 mg KOH/g), B $(0.75 \mathrm{mg} \mathrm{KOH} / \mathrm{g})$, $\mathrm{C}(0.47 \mathrm{mg} \mathrm{KOH} / \mathrm{g}), \mathrm{D}(0.30 \mathrm{mg} \mathrm{KOH} / \mathrm{g})$, and $\mathrm{E}(0.18 \mathrm{mg} \mathrm{KOH} / \mathrm{g})$. Contact angles and improved Amott water indexes were measured to study the effects of temperature and acid number on the wettability of the acid volcanic reservoir rock. Experimental results indicated that the wettability was not sensitive to variation in temperature when using the same oil, but the acid number of the crude oil was a key factor in changing the wettability of the rock. The Amott water index, $I_{\mathrm{w}}$ was an exponential function of the acid number, and the Amott water index increased as the acid number decreased (i.e. Amott water index exponentially decreased with the acid number increase). The $I_{\mathrm{w}}$ value of the core saturated with oil A, with an acid number of $2.09 \mathrm{mg} \mathrm{KOH} / \mathrm{g}$, ranged from 0.06 to 0.11 , which indicated low water wetness. If the acid number of the oil decreased to $0.18 \mathrm{mg} \mathrm{KOH} / \mathrm{g}$, the $I_{\mathrm{w}}$ value increased to 0.95 , which indicated strong water wetness. The contact angle decreased from $80^{\circ}$ to $35^{\circ}$ when the aid number decreased from 0.75 to $0.18 \mathrm{mg} \mathrm{KOH} / \mathrm{g}$, indicating a change towards more water wet conditions. The oil recovery by spontaneous imbibition of water also increased as the acid number of the oil decreased. As an example, at $80{ }^{\circ} \mathrm{C}$, the recovery of Oil A with an acid number of $2.09 \mathrm{mg} \mathrm{KOH} / \mathrm{g}$ was only $7.6 \%$, while Oil E with an acid number of $0.18 \mathrm{mg} \mathrm{KOH} / \mathrm{g}$ produced $56.4 \%$, i.e. an increase of $48.8 \%$.
\end{abstract}

Key words: Acid volcanic reservoir rock, Amott wettability index, wetting angle, temperature, acid number, wettability

\section{Introduction}

The reason why oil recovery from volcanic reservoirs world-wide is believed to be less than $30 \%$ of the initial oil in place is that most of the volcanic reservoir rocks are neutral to preferential oil-wet, which makes water flooding less effective as an enhanced oil recovery (EOR) technique. Moreover, the volcanic reservoir rocks in many cases are highly fractured, which makes water flooding even worse. The recovery of the crude oil in the matrix that depends on spontaneous imbibition is becoming more and more significant for these types of reservoirs.

The wetting condition of a reservoir rock is closely related to the stability of the water film between the rock and the oil (Hirasaki and Zhang, 2003). Over the past five decades many experiments have been conducted aimed at studying the

*Corresponding author. email: xqeor2858@163.com

Received December 25, 2008 wettability of sandstone and carbonate reservoirs. However, the majority of experiments concentrated on the influence of asphaltenes on the wettability of reservoirs since many researchers believed that the adsorption of asphaltenes on the rock surface results in a variation in wettability. For carbonate reservoirs, naphthenic acids and a number of carboxylic acids are recognized to be the most frequent acidic components that absorbed on the rock surface and altered its wettability (Anderson, 1986a; 1986b; Madsen and Lind, 1998; Legens et al, 1998; Hansen et al, 2000). Some investigations show that $90 \%$ of carbonate oil reservoirs are characterized as neutral compared with preferential oil-wet reservoirs, and it is documented that the water wetting nature increases as the temperature increases - which is opposite to the behavior of sandstone reservoirs (Madsen and Lind, 1998; Rao, 1999). Wettability of calcite can be altered from intermediate-wet to preferentially water-wet with alkaline/surfactant systems. Anionic surfactant adsorption can be significantly reduced in the presence of sodium carbonate (Zhang et al, 2006). For 
the Yates reservoir rock-fluids system, an ethoxy alcohol surfactant altered the strongly oil-wet nature (an advancing contact angle of $\left.158^{\circ}\right)$ to water-wet $\left(39^{\circ}\right)$ at a concentration of 3,500 ppm (Vijapurapu and Rao, 2004). Many authors have reported a shift in wettability of mineral surfaces toward water-wet at increased temperatures (Wang and Gupta, 1995; Al-Hadhrami and Blunt, 2000; Schembre and Kovscek, 2004). The value and sign of the zeta potentials of the oilwater and the water-solid interfaces will dictate the wetting state of the reservoir rock. The charge of the oil-water interface is usually negative due to the content of carboxylic acids in the crude oil (Hamouda and Gomari, 2006). Zhang and Austad (2005) proposed that the acid number was the dominant wetting parameter, and the aging temperature only played a very minor role in determining the wetting conditions of chalk wettability.

Most papers did not consider the factors of temperature and acid number which have a significant impact on the wettability of reservoir rock. It is nevertheless well known from organic geochemistry that the acid number of crude oil is related to the reservoir temperature as decarboxylation takes place with temperature increase (Shimoyama and Johns, 1971; Hamouda and Gomari, 2006). But whether the decarboxylation will happen in a short time (30 days in the laboratory) or not, has not been researched extensively in terms of what factor contributes most to the wettability of acidic volcanic reservoir rocks. The current work is dedicated to quantifying the influence of temperature and acid number on the variation of wettability of acid volcanic rock from the Hailar Oilfield, China.

\section{Lithologic characteristics of acid volcanic rock}

Many experiments including thin section analysis, scanning electronic microscopy (SEM), X-ray diffraction (XRD) analysis, and bulk-rock analysis, indicated that the Hailar acid volcanic rock is a secondary eruptive acid volcanic tuff and 98 percent of its mass is composed of volcanic dust which has become argillaceous. Feldspar, authigenic quartz in pore spaces, and albite crystals were observed by means of SEM. The contents of silicon dioxide, potassium oxide, and iron oxide in the rock sample were $71.06 \%, 6.97 \%$, and $3.27 \%$, respectively. Experimental cores were from the Bei 28 well drilled in the Hailar Oilfield, China, with a sampling depth of 1,655-1,680 m. The X-ray diffraction results of cores taken from different depth intervals are listed in Table 1.

Table 1 X-ray diffraction results of core samples

\begin{tabular}{|c|c|c|c|c|c|c|c|c|c|c|c|}
\hline \multirow{2}{*}{$\begin{array}{c}\text { Core } \\
\text { sample }\end{array}$} & \multirow{2}{*}{$\begin{array}{l}\text { Depth } \\
\mathrm{m}\end{array}$} & \multirow{2}{*}{$\begin{array}{c}\text { Quartz } \\
\%\end{array}$} & \multirow{2}{*}{$\begin{array}{c}\text { Potassic feldspar } \\
\%\end{array}$} & \multirow{2}{*}{$\begin{array}{c}\text { Plagioclase } \\
\%\end{array}$} & \multirow{2}{*}{$\begin{array}{l}\text { Zeolite } \\
\%\end{array}$} & \multirow{2}{*}{$\begin{array}{c}\text { Clay } \\
\%\end{array}$} & \multicolumn{5}{|c|}{ Relative content of clay mineral } \\
\hline & & & & & & & M & $\mathrm{I} / \mathrm{M}$ & I & K & $\mathrm{C}$ \\
\hline Y1 & 1655.7 & 31.8 & 21 & - & 9.7 & 37.5 & 0 & 80 & 12 & 3 & 5 \\
\hline Y2 & 1667.3 & 36.2 & - & 16 & 6.3 & 41.5 & 5 & 84 & 3 & 7 & 1 \\
\hline Y8 & 1675.4 & 33.8 & 19 & - & 7.7 & 39.5 & 0 & 90 & 1 & 4 & 5 \\
\hline
\end{tabular}

Notes: M: Montmorillonite; I: Illite; K: Kaolinite; C: Chlorite; I/M: Mixed-layer illite-montmorillonite

\section{Experimental}

\subsection{Core plug selection}

The core material for wettability measurement was cut with $\mathrm{KCl}$ brine and packed under $\mathrm{KCl}$ brine in plastic bottles. No other chemical additives such as defoamer or surfactant were used to minimize any possible alternation of the core wettability. Core plugs of approximately $2.5 \mathrm{~cm}$ in diameter and $5.0 \mathrm{~cm}$ in length were cut from an entire core, which was drilled from the volcanic reservoir rock from the Bei 28 well with brine identical to the preserving $\mathrm{KCl}$ brine used as drilling fluid. The sampling direction of experimental cores was perpendicular to the axis of the whole core.
The experimental cores had porosity and permeability of $19 \%-22 \%$ and $2-5 \mathrm{mD}$, respectively.

\subsection{Experimental fluids}

The brine used in contact angle tests and improved Amott tests for wettability was actual formation water from the Hailar Oilfield. Before use, the formation water was filtered with a membrane filter $(0.45 \mu \mathrm{m}$ pore size $)$ twice to remove suspended matter in the brine. The composition of the formation water is listed in Table 2. The main components of the formation water were sodium and potassium cations and bicarbonate anions.

The crude oil used to prepare oil samples was sampled from the wellhead of the Hailar Oilfield and its acid number

Table 2 Properties of the formation water used

\begin{tabular}{|c|c|c|c|c|c|c|c|c|c|}
\hline \multirow{2}{*}{ Water type } & \multirow{2}{*}{$\begin{array}{c}\mathrm{pH} \\
\text { value }\end{array}$} & \multirow{2}{*}{$\begin{array}{c}\text { Salinity } \\
\mathrm{mg} / \mathrm{L}\end{array}$} & \multicolumn{7}{|c|}{ Composition of formation water, $\mathrm{mg} / \mathrm{L}$} \\
\hline & & & $\mathrm{CO}_{3}^{2-}$ & $\mathrm{HCO}_{3}^{-}$ & $\mathrm{SO}_{4}{ }^{2-}$ & $\mathrm{Cl}^{-}$ & $\mathrm{Ca}^{2+}$ & $\mathrm{Mg}^{2+}$ & $\mathrm{Na}^{+}+\mathrm{K}^{+}$ \\
\hline $\mathrm{NaHCO}_{3}$ & 8.32 & 5180 & 59.1 & 3340 & 20.6 & 273 & 9.02 & 3.65 & 1470 \\
\hline
\end{tabular}


was $3.05 \mathrm{mg} \mathrm{KOH} / \mathrm{g}$. The approach proposed by Zhang and Austad (2005) of making experimental oil samples with different acid numbers was adopted in this study.

The crude oil was diluted with heptane in a ratio of $40 / 60$ by volume (because it's extremely easy to measure and calculate in the laboratory) to get Oil A. Oil A was filtered through a 5- $\mu \mathrm{m}$ Millipore filter and no precipitation of asphaltenes was observed. The acid number of Oil A was $2.09 \mathrm{mg} \mathrm{KOH} / \mathrm{g}$. Oil E was prepared by silica gel treatment of Oil A to remove surface active material. About $10 \mathrm{wt} \%$ of silica gel was added to the oil and the mixture was stirred at room temperature for 72 hours. Then a similar amount of silica gel was added to the mixture, and it was stirred for 48 hours. The oil was then centrifuged and filtered through a $5-\mu \mathrm{m}$ Millipore filter. After treatment, the acid number of Oil E was determined to be $0.18 \mathrm{mg} \mathrm{KOH} / \mathrm{g}$. Oils with different acid numbers (Oil B, C, and D) were then made by mixing Oil A with Oil E in different ratios as listed in Table 3. The interfacial tension (IFT) between the oils and the formation brine from the Hailar Oilfield were measured at $50{ }^{\circ} \mathrm{C}$.

Table 3 Properties of the oils used

\begin{tabular}{cccccc}
\hline Oil sample & $\begin{array}{c}\text { Acid number } \\
\mathrm{mg} \mathrm{KOH} / \mathrm{g}\end{array}$ & $\begin{array}{c}\text { Density } \\
\mathrm{g} / \mathrm{cm}^{3}\end{array}$ & $\begin{array}{c}\text { Viscosity } \\
\mathrm{mPa} \cdot \mathrm{s}\end{array}$ & $\begin{array}{c}\mathrm{IFT} \\
\mathrm{mN} / \mathrm{m}\end{array}$ & $\begin{array}{c}\text { Remark } \\
\text { Ratio of A to E (by volume) }\end{array}$ \\
\hline $\mathrm{A}$ & 2.09 & 0.810 & 3.14 & 18.2 & - \\
$\mathrm{B}$ & 0.75 & 0.804 & 2.72 & 18.1 & $1: 2$ \\
$\mathrm{C}$ & 0.47 & 0.802 & 2.52 & 18.0 & $1: 5$ \\
$\mathrm{D}$ & 0.30 & 0.801 & 2.39 & 18.2 & $1: 15$ \\
$\mathrm{E}$ & 0.18 & 0.801 & 2.26 & 18.3 & - \\
\hline
\end{tabular}

\subsection{Wettability measurements}

Because the Amott test is not extremely sensitive to neutral conditions, high temperature and pressure interfacial tension apparatus provided by Kruss Company, Germany, was used to test the contact angle between formation water and the cores. The cores evacuated were saturated with formation brine from the Hailar Oilfield and then aged for 30 days in crude oil at different temperatures (40, 60, 80, 100, and $120^{\circ} \mathrm{C}$ ) before wettability measurements.

\subsubsection{Amott water index method}

The Amott test is one of the most widely used empirical wettability measurements for reservoir cores in petroleum engineering. Wettabilities of preserved core plugs were measured with the improved Amott water index method which is slightly different from the conventional procedure. This Amott water index approach combines spontaneous imbibition and dynamic displacement that is conducted under ambient conditions with formation water and crude oil. The experimental procedures adopted in this paper are as follows.

1) Core plugs of approximately $2.5 \mathrm{~cm}$ in diameter and 5.0 $\mathrm{cm}$ in length were cut from the whole core, which was drilled from the Bei 28 well with brine identical to the preserving $\mathrm{KCl}$ brine used as drilling fluid.

2) Thin slices about $0.5 \mathrm{~cm}$ thick were cut from both sides of the core plugs ( $\mathrm{KCl}$ solution was used for cooling). Then the cut core plugs and thin slices were dried at $90{ }^{\circ} \mathrm{C}$ to constant weight.

3) The core plugs were evacuated for 10 hours, and then were saturated with formation water for another 10 hours at room temperature. The porosity of the core could be calculated from the bulk volume of the rock and the weight difference between dry weight and the weight of core saturated with formation brine.
4) Afterwards, the initial water saturation (i.e. irreducible water saturation), $S_{\mathrm{wi}}$ was established at room temperature by injecting 2.0-2.5 pore volume (PV) of actual crude oil in each direction with a confining pressure not exceeding 3 $\mathrm{MPa}$. The crude oil was injected at a rate of $0.01 \mathrm{~mL} / \mathrm{min}$. The low displacement rate meant little or no damage to the pore structure because the original permeability of the core was extremely low (about $2-5 \mathrm{mD}$ ). If the pore structure is damaged by a high rate of displacement and causes velocity sensitivity, the experimental data of the Amott water index would not be reliable. The volume of the formation water displaced by the crude oil and the weight of the core before oil displacement were measured to calculate the $S_{\mathrm{wi}}$.

5) The core plugs were flooded with formation brine at room temperature to obtain the $S_{\text {or }}$. The volume of oil displaced by the formation brine and the weight of the core before brine displacement were measured to calculate the $S_{\text {or }}$.

6) Spontaneous imbibition tests were performed at different temperatures $\left(40,60,80,100\right.$, and $\left.120^{\circ} \mathrm{C}\right)$ to obtain the $S_{\text {ws }}$ after step 4) was repeated to saturate the core plug with oils. The procedures of spontaneous imbibition tests were as follows: Firstly, the core plug was put in a steel imbibition cell which was full of formation brine and a back-pressure of $1 \mathrm{MPa}$ was applied to keeping the fluids below the bubble point during the whole test period (30 days). Then the steel imbibition cell was kept in an oven which was maintained at a given temperature. Finally, a burette, which was connected with the top of the steel imbibition cell, was used to measure the volume of oil displaced by spontaneous brine imbibition.

7) The volume of the oil displaced by spontaneous imbibition of water was combined with the weight of core plug saturated with brine and oils to calculate the $S_{\mathrm{ws}}$.

The Amott water index was determined based on the 
measured water and oil saturations (Anderson, 1986; Morrow, 1990).

$$
I_{\mathrm{w}}=\frac{S_{\mathrm{ws}}-S_{\mathrm{wi}}}{S_{\mathrm{wf}}-S_{\mathrm{wi}}}=\frac{S_{\mathrm{ws}}-S_{\mathrm{wi}}}{1-S_{\mathrm{or}}-S_{\mathrm{wi}}}
$$

where $S_{\text {or }}$ is the residual oil saturation; $S_{\mathrm{wi}}$ is the initial water saturation; $S_{\mathrm{wf}}$ is the water saturation after water flooding; $S_{\mathrm{ws}}$ is the water saturation after spontaneous imbibition of water.

\subsubsection{Contact angle test}

In the laboratory, pendant drop measurement was used to test the wettability of the core surface. Polished circular natural rock plates with a thickness of $0.15-0.2 \mathrm{~cm}$ were used as substrates in contact angle measurements. The contact angle measurements were performed at $15 \mathrm{MPa}$ (reservoir pressure) and at a specified temperature $(40,60,80,100$, or $120^{\circ} \mathrm{C}$, respectively). The procedures of contact angle test are as follows:

1) The oil and formation brine were poured into their individual containers; and then the oil and brine were taken into corresponding cylinders by means of the manual pumps.

2) The core plate was carried by a frame of fine wire in the measurement cell which was provided by the manufacturer of interfacial tensiometer. In this case, the core plate was suspended horizontally in the cell.

3) The formation brine was injected from the bottom of the measurement cell with a manual pump to make sure that the entire measurement cell was filled with formation brine. The valve on the top of the measurement cell was closed after excess formation brine was ejected from the cell.

4) The pressure of the measurement cell was elevated to reach $15 \mathrm{MPa}$ which was equal to the reservoir pressure of the Hailar Oilfield. The interfacial tensiometer can offer different pressures (ranging from 0.1 to $80 \mathrm{MPa}$ ).

5) The oils were injected on the bottom surface of the core plates by the means of the small pipe from the bottom of the measurement under control of the manual pump.

6) Then the temperature of the cell was set up and gradually the temperature of the brine was increased until it reached the set temperature. The interfacial tensiometer can provide different temperatures (ranging from 20 to $180{ }^{\circ} \mathrm{C}$ ).

7) The variation in the contact angle was observed through the window in the interfacial tensiometer cell. The contact angle was directly recorded through the water phase with an automatic camera and a data logging device installed in the interfacial tensiometer.

\section{Experimental results and discussion}

\subsection{The effect of temperature on the wettability of acid volcanic reservoir rock}

Fig. 1 and Table 4 showed that the aging temperature had only very minor effect on wetting conditions. The wetting properties were determined by the acid number of the crude oil. The same phenomenon was also observed in contact angle tests (Fig. 2), which indicated that the contact angle decreased with increasing aging temperature when using the same oil.

According to molecular adsorption theory, the restraining ability of pore surfaces to polar molecules in the oil decreases because the thermal motion of the molecules increases as the temperature increases. In this case, water molecules occupy the rock surface whereas the polar molecules remove their polar end from the rock surface. As a matter of fact, increasing the thermal motion of molecules by increasing the temperature has an extremely minor effect on wetting conditions. The wetting properties are determined by the acid number, as shown in Fig. 1. Contact angle, however, obviously decreased as the acid number of crude oil decreased. The decreasing trend of the contact angle became apparent as the acid number reached $0.75 \mathrm{mg}$ $\mathrm{KOH} / \mathrm{g}$. The contact angle decreased from 80 to 35 degrees when the acid number of crude oil decreased from 0.75 to $0.18 \mathrm{mg} \mathrm{KOH} / \mathrm{g}$. The results from contact angle tests were matched with the results from Amott wettability index tests. Another interesting phenomenon was that the effect of aging temperature on contact angle became more and more prominent as the acid number increased (Fig. 1). In view of the molecular adsorption theory and the physical properties of the experimental oil, the content of polar organic matter in the crude oil of high acid number is larger than that in the crude oil of low acid number. In this way, polar molecules, which removed their polar ends from the pore surface, became more numerous in the high acid number oil under the impact of thermal motion of molecules.

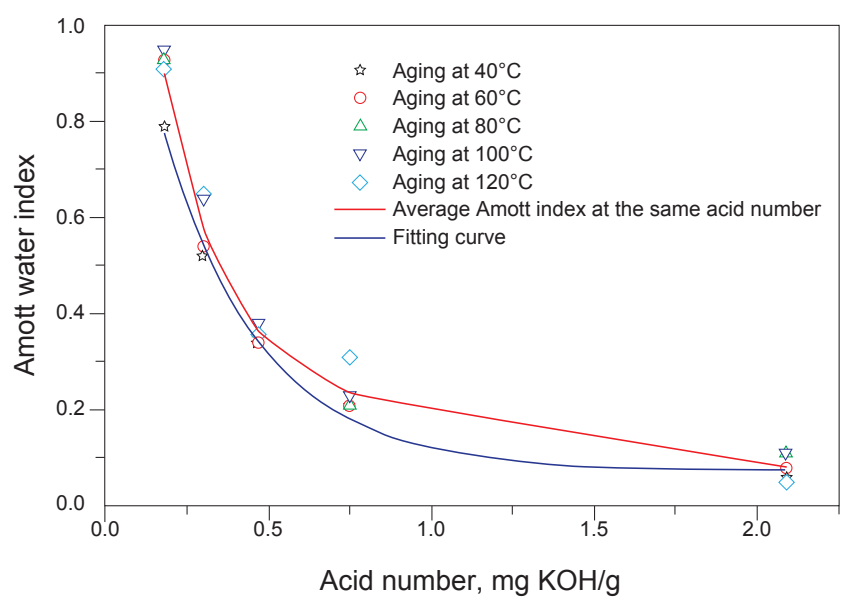

Fig.1 Relationship between acid number and Amott index for cores aged at different temperatures

From a geochemical point of view, the relationship between the content of carboxylic acid in crude oil and the temperature is of interest. It is widely recognized that clay minerals (montmorillonite for example) can act as a catalyst in the generation of hydrocarbon from fatty acids. Thus in a volcanic reservoir rock, the formation itself with the abundant clay minerals (especially montmorillonite and mixedlayer illite-montmorillonite minerals) can act as a catalyst to decompose carboxylic materials. The catalytic effect of montmorillonite and illite-montmorillonite nevertheless speed up a very slow reaction so that it becomes important during the geological time. This observation is of course very interesting from a wettability and fluid flow point of view for volcanic reservoir rock. It explains the reason why Rao (1999) observed that the water-wetness of carbonate reservoirs (which can also act as a catalyst in the generation 
of hydrocarbon from fatty acids) increased with temperature. It is however, not because of the temperature itself, but a decrease in the carboxylic groups because of catalytic decomposition during geological time (Zhang and Austad, 2005). The experiments we had performed showed that the acid number of crude oil dictated the wettability of acid volcanic reservoir rock. The water wettability increased as the acid number of crude oil decreased. However, the wettability of this volcanic reservoir rock changed sharply from oil-wet to water-wet as the acid number of crude oil droped below 0.75 $\mathrm{mg} \mathrm{KOH} / \mathrm{g}$.

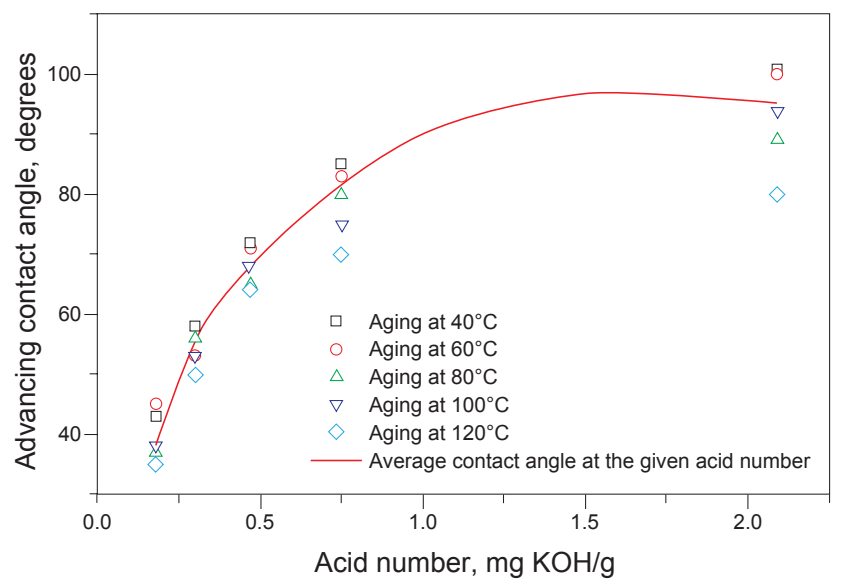

Fig. 2 Relationship between advancing contact angle and acid number of oil

\subsection{The effect of acid number of crude oil on acid volcanic reservoir rock}

This paper investigated the wettability index of different crude oils (acid number: $2.09,0.75,0.47,0.30$, and $0.18 \mathrm{mg}$ $\mathrm{KOH} / \mathrm{g})$ at different temperatures $(40,60,80,100$, and 120 ${ }^{\circ} \mathrm{C}$ ), as shown in Table 4. The experimental results illustrated that the initial water saturation of cores saturated with crude oils of different acid numbers changed significantly. Its value ranged from $29 \%$ to $32 \%$ for cores saturated with Oil A of high acid number $(2.09 \mathrm{mg} \mathrm{KOH} / \mathrm{g})$ and from $38 \%$ to $39 \%$ for cores saturated with Oil E of low acid number $(0.18$ $\mathrm{mg} \mathrm{KOH} / \mathrm{g}$ ), respectively. A possible reason for this is the difference in viscosity of crude oils of different acid numbers (Table 2). The initial water saturation of cores saturated with Oil A with a viscosity of $3.14 \mathrm{cp}$ was lower than that of cores saturated with Oil E with a viscosity of $2.26 \mathrm{mPa} \cdot \mathrm{s}$. Amott wettability index tests showed that the Amott water index tended to decrease exponentially with an increase in the acid number of the crude oil (Fig. 1). The Amott water index ranged from 0.06 to 0.11 for the core saturated with Oil A, which indicated low water wetness. However, the Amott wettability index increased from 0.11 to 0.95 as the acid number of crude oil decreased from 2.09 to $0.18 \mathrm{mg} \mathrm{KOH} / \mathrm{g}$, which indicated strong water-wetness. The Amott water index increased quickly with the decrease in acid number when the acid number was below $0.75 \mathrm{mg} \mathrm{KOH} / \mathrm{g}$ and the influence

Table 4 Physical properties of cores tested and the main Amott test results

\begin{tabular}{|c|c|c|c|c|c|c|c|c|c|c|c|c|}
\hline \multirow{2}{*}{$\begin{array}{c}\text { Oil } \\
\text { sample }\end{array}$} & \multirow{2}{*}{$\begin{array}{c}\text { Acid } \\
\text { number }\end{array}$} & \multirow{2}{*}{$\begin{array}{c}\text { Core } \\
\text { sample }\end{array}$} & \multicolumn{5}{|c|}{ Core properties } & \multirow{2}{*}{$\begin{array}{c}\text { Aging } \\
\text { temperature } \\
{ }^{\circ} \mathrm{C}\end{array}$} & \multicolumn{4}{|c|}{ Amott test } \\
\hline & & & $\begin{array}{c}\text { Diameter } \\
\mathrm{cm}\end{array}$ & $\begin{array}{c}\text { Length } \\
\mathrm{cm}\end{array}$ & $\begin{array}{c}\text { Pore volume } \\
\mathrm{mL}\end{array}$ & $\begin{array}{c}\text { Porosity } \\
\%\end{array}$ & $\begin{array}{c}S_{\mathrm{wi}} \\
\%\end{array}$ & & $\begin{array}{c}S_{\mathrm{ws}} \\
\%\end{array}$ & $\begin{array}{l}S_{\mathrm{w}} \\
\%\end{array}$ & $\begin{array}{c}\text { Imbibition } \\
\%\end{array}$ & $I_{\mathrm{w}}$ \\
\hline \multirow{4}{*}{ Oil A } & \multirow{4}{*}{2.09} & $1-1$ & 2.50 & 4.88 & 9.88 & 21.1 & 26.8 & 40 & 29.5 & 75.1 & 3.7 & 0.06 \\
\hline & & $1-2$ & 2.51 & 4.89 & 9.79 & 20.8 & 25.7 & 60 & 29.7 & 75.8 & 5.4 & 0.08 \\
\hline & & $1-3$ & 2.49 & 4.91 & 9.96 & 21.1 & 26.5 & 80 & 32.1 & 76.9 & 7.6 & 0.11 \\
\hline & & $1-4$ & 2.49 & 4.65 & 9.23 & 21.8 & 26.3 & 100 & 31.5 & 75.8 & 7.1 & 0.11 \\
\hline \multirow{5}{*}{ Oil B } & \multirow{5}{*}{0.75} & $2-1$ & 2.50 & 4.89 & 9.89 & 21.1 & 29.4 & 40 & 38.7 & 74.1 & 13.2 & 0.21 \\
\hline & & $2-2$ & 2.52 & 4.79 & 9.89 & 21.8 & 29.7 & 60 & 39.2 & 75.9 & 13.5 & 0.21 \\
\hline & & $2-3$ & 2.48 & 4.90 & 9.99 & 21.4 & 29.5 & 80 & 39.8 & 77.9 & 14.6 & 0.21 \\
\hline & & $2-4$ & 2.49 & 5.01 & 9.89 & 20.2 & 29.8 & 100 & 41.2 & 78.8 & 16.2 & 0.23 \\
\hline & & $2-5$ & 2.52 & 5.03 & 9.97 & 19.9 & 29.1 & 120 & 42.5 & 72.0 & 18.9 & 0.31 \\
\hline \multirow{5}{*}{ Oil C } & \multirow{5}{*}{0.47} & $3-1$ & 2.51 & 5.01 & 9.88 & 20.0 & 32.8 & 40 & 48.2 & 78.1 & 22.9 & 0.34 \\
\hline & & $3-2$ & 2.51 & 5.00 & 9.87 & 20.0 & 33.1 & 60 & 47.6 & 78.2 & 21.8 & 0.32 \\
\hline & & $3-3$ & 2.50 & 4.89 & 9.97 & 21.3 & 32.8 & 80 & 47.9 & 75.1 & 22.5 & 0.36 \\
\hline & & $3-4$ & 2.47 & 4.78 & 9.88 & 22.3 & 32.6 & 100 & 49.1 & 75.8 & 24.5 & 0.38 \\
\hline & & $3-5$ & 2.48 & 5.04 & 9.98 & 20.2 & 33.2 & 120 & 48.7 & 76.1 & 23.2 & 0.36 \\
\hline \multirow{5}{*}{ Oil D } & \multirow{5}{*}{0.30} & 4-1 & 2.50 & 5.02 & 9.88 & 20.0 & 36.7 & 40 & 56.8 & 75.1 & 31.8 & 0.52 \\
\hline & & $4-2$ & 2.51 & 4.80 & 9.87 & 21.7 & 36.4 & 60 & 59.3 & 78.8 & 36.0 & 0.54 \\
\hline & & $4-3$ & 2.48 & 4.98 & 9.96 & 20.6 & 36.2 & 80 & 57.2 & 76.6 & 32.9 & 0.52 \\
\hline & & $4-4$ & 2.50 & 4.78 & 9.90 & 22.1 & 36.7 & 100 & 59.1 & 71.8 & 35.4 & 0.64 \\
\hline & & $4-5$ & 2.48 & 4.90 & 9.92 & 21.2 & 36.4 & 120 & 58.8 & 71.1 & 35.2 & 0.65 \\
\hline \multirow{4}{*}{ Oil E } & \multirow{4}{*}{0.18} & $5-1$ & 2.48 & 4.93 & 9.90 & 20.9 & 39.1 & 40 & 69.2 & 77.1 & 49.4 & 0.79 \\
\hline & & $5-2$ & 2.51 & 4.88 & 9.92 & 21.1 & 38.7 & 60 & 68.1 & 75.8 & 48.0 & 0.79 \\
\hline & & $5-3$ & 2.51 & 5.03 & 9.96 & 20.0 & 38.5 & 80 & 73.2 & 75.9 & 56.4 & 0.93 \\
\hline & & $5-4$ & 2.49 & 4.90 & 9.95 & 21.2 & 38.8 & 100 & 78.3 & 80.5 & 64.5 & 0.95 \\
\hline
\end{tabular}


of the acid number on the wettability became weak when the acid number was beyond $0.75 \mathrm{mg} \mathrm{KOH} / \mathrm{g}$. This phenomenon is similar to the results from Strand et al (2004). Their research indicated that the wettability index of carbonate rocks decreased very little when the acid number increased beyond $1.0 \mathrm{mg} \mathrm{KOH} / \mathrm{g}$.

\subsection{The effects of temperature and acid number of oil on oil recovery}

The effects of temperature and acid number of oil on oil recovery were analyzed on the basis of wettability index tests and experimental results are shown in Fig. 3. In order to understand the effect of capillary imbibition on oil recovery, this paper presents the interfacial tension (IFT) between injection water and oil at different temperatures. It can be seen from Fig. 4 that the IFT decreased slightly as the temperature increased, and it dropped by $8.7 \%$ as the temperature increased from 40 to $120{ }^{\circ} \mathrm{C}$. It is interesting to note that for the oil with the same acid number, the oil recovery was independent on the temperature. A small decrease in IFT did not affect the oil recovery according to Figs. 4 and 5. On the contrary, oil recovery was closely related to the acid number. Oil recovery by imbibition increased as the acid number decreased. For example, at $80{ }^{\circ} \mathrm{C}$, the recovery of Oil A (2.09 $\mathrm{mg} \mathrm{KOH} / \mathrm{g}$ ) was only $7.6 \%$, while Oil E $(0.18 \mathrm{mg} \mathrm{KOH} / \mathrm{g})$ showed a recovery of $56.4 \%$ (i.e. an increase of $48.8 \%)$. This demonstrates that the volcanic reservoir rock containing crude oil with a low acid number is inclined to be strongly water-wet, and oil recovery will be improved by means of capillary imbibition instead of by variation of temperature in the reservoir. Rao (1999) observed that the water-wetness of carbonate reservoirs increased with temperature. It is not, however, because of the temperature itself, but because of a decrease in the carboxylic groups from catalytic decomposition during geological time (Jurg and Eisma, 1964). It also supported that the acid number is, as pointed out previously, the key parameter dictating the wetting conditions of volcanic reservoir rocks rich in clay minerals (especially montmorillonite). We surely do not expect any significant change in the acid number during the aging period of 30 days in our experiments even at $120{ }^{\circ} \mathrm{C}$ because the decarboxylation is a rather slow process.

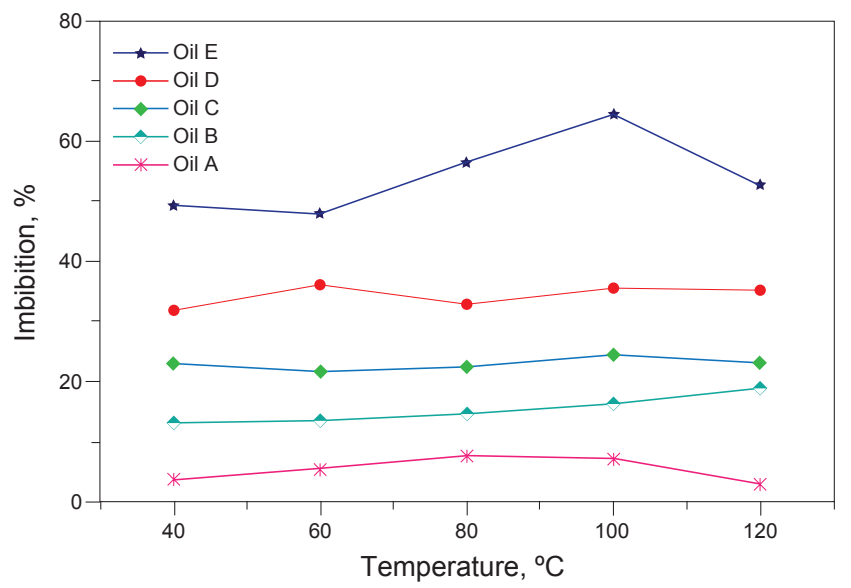

Fig. 3 Relationship between imbibition and temperature

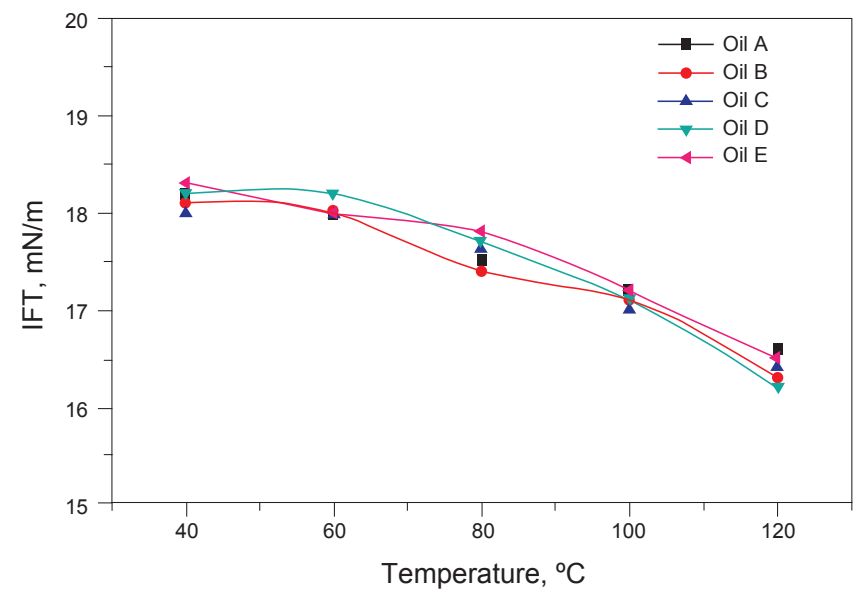

Fig. 4 Relationship between IFT and temperature

\section{Conclusions}

Laboratory experiments have been designed to experimentally separate the effects of acid number and temperature on wetting parameters of a volcanic reservoir rock. The cores (which contained initial formation water and crude oil of different acid numbers $(0.18-2.09 \mathrm{mg} \mathrm{KOH} /$ g)) were aged in the corresponding crude oils at different temperatures $\left(40-120^{\circ} \mathrm{C}\right)$ for 30 days. The relative effects of temperature and acid number on the wettability of acid volcanic reservoir rock from the Hailar Oilfield, China were characterized by Amott wettability index and contact angle. The following conclusions are drawn:

1) The wettability of the volcanic reservoir rock was mainly dictated by the acid number of crude oil. The water wetness of the rock increased as the acid number decreased. However, the effect of temperature on the wettability of the volcanic reservoir rock was negligible over a 30 day aging period.

2) The Amott wettability index tended to decrease exponentially as the acid number of crude oil increased. The wettability index of reservoir rock saturated with Oil A (with an acid number of $2.09 \mathrm{mg} \mathrm{KOH} / \mathrm{g}$ ) ranged from 0.06 to 0.11 , which showed the rock was low water wetness. However, the Amott wettability index increased to 0.95 as the acid number of crude oil droped to $0.18 \mathrm{mg} \mathrm{KOH} / \mathrm{g}$, which showed that the rock was then strongly water-wet.

3) The Amott wettability index increased quickly with a decrease in acid number when the acid number of crude oil was below $0.75 \mathrm{mg} \mathrm{KOH} / \mathrm{g}$, and the influence of acid number on wettability became weak when the acid number was higher than $0.75 \mathrm{mg} \mathrm{KOH} / \mathrm{g}$.

4) The oil recovery by spontaneous imbibition of water also increased as the acid number of the oil decreased.

\section{References}

Al-Hadhrami $\mathrm{H}$ and Blunt M. Thermally induced wettability alteration to improve oil recovery in fractured reservoirs. Paper SPE 71866 presented at SPE/DOE Improved Oil Recovery Symposium, Tulsa, Oklahoma, 3-5 April 2000

Anderson W G. Wettability literature survey - Part 1: rock/oil/brine 
interactions and the effects of core handling on wettability. Journal of Petroleum Technology. 1986a. 38(10): 1125-1144 (Paper SPE 13932-PA)

Anderson W G. Wettability literature survey - Part 2: wettability measurement. Journal of Petroleum Technology. 1986b. 38(11): 1246-1262 (Paper SPE 13933-PA)

Hamouda A A and Gomari K A R. Influence of temperature on wettability alteration of carbonate reservoirs. Paper SPE 99848 presented at SPE/DOE Symposium on Improved Oil Recovery, Tulsa, Oklahoma, 22-26 April 2006

Hansen G, Hamouda A A and Denoyel R. Effect of pressure on contact angles and wettability in the mica/water/ $n$-decane system and the calcite+stearic acid/water/ $n$-decane system. Colloids Surfaces. 2000 . 172: 7

Hirasaki G and Zhang D L. Surface chemistry of oil recovery from fractured, oil-wet, carbonate formation. Paper SPE 80988 presented at SPE International Symposium on Oilfield Chemistry, Houston, Texas, 5-8 February 2003

Jurg J W and Eisma E. Petroleum hydrocarbons: generation from fatty acid. Science. 1964. 144: 1451-1452

Legens C, Toulhoat H, Cuiec L, et al. Wettability change related to the adsorption of organic acids on calcite. Paper SPE 49319 presented at SPE Annual Technical Conference and Exhibition, Louisiana, New Orleans, 27-30 September 1998

Madsen L and Lind I. Adsorption of carboxylic acids on reservoir minerals from organic and aqueous phase. SPE Reservoir Evaluation and Engineering. 1998. (1): 47-51 (Paper SPE 37292)

Morrow N R. Wettability and its effect on oil recovery. Journal of Petroleum Technology. 1990. 42(12): 1476-1484

Rao D N. Wettability effects in thermal recovery operation. Paper SPE
57897 presented at SPE 10th Symposium on Improved Oil Recovery, Tulsa, Oklahoma, 21-24 April 1999

Schembre J M and Kovscek A R. Thermally induced fines mobilization: its relationship to wettability and formation damage. Paper SPE 86937 presented at SPE International Thermal Oil Symposium and Western Regional Meeting, California, Bakersfield, 16-18 March 2004

Shimoyama A and Johns W D. Catalytic conversion of fatty acids to petroleum-like paraffins and their maturation. Nature Physical Science. 1971. 232: 140-144

Strand S, Standnes D C and Austad T. New wettability test for chalk. 8th International Symposium on Reservoir Wettability and its Effect on Oil Recovery, Rice University, Houston, 16-18 May 2004

Vijapurapu C S and Rao D N. Compositional effects of fluids on spreading, adhesion and wettability in porous media. Colloids and Surfaces A: Physicochemical and Engineering Aspects. 2004. 241(1-3): 335-342

Wang W and Gupta A. Investigation of the effect of temperature and pressure on wettability using modified pendant drop method. Paper SPE 30544 presented at SPE Annual Technical Conference and Exhibition, Dallas, 22-25 October 1995

Zhang D L, Liu S, Puerto M, et al. Wettability alteration and spontaneous imbibition in oil-wet carbonate formations. Journal of Petroleum Science and Engineering. 2006. 52: 213-226

Zhang $\mathrm{P}$ and Austad T. The relative effects of acid number and temperature on chalk wettability. Paper SPE 92999 presented at SPE International Symposium on Oilfield Chemistry, Houston, Texas, 2-4 February 2005

(Edited by Sun Yanhua) 